\title{
HUBUNGAN ANTARA KEHAMILAN POSTTERM DAN KETUBAN PECAH DINI DENGAN ASFIKSIA PADA BAYI BARU LAHIR DI RSUD ‘45’ KABUPATEN KUNINGAN TAHUN 2016
}

\author{
Wida Wisudawati \\ Dosen Akademi Kebidanan Assyifa Tangerang \\ Email : sahrul.bhitan@yahoo.co.id
}

\begin{abstract}
ABSTRAK
Penyebab utama kematian bayi baru lahir adalah asfiksia pada bayi baru lahir, asfiksia dapat dipengaruhi oleh kehamilan postterm dan ketuban pecah dini. Di RSUD “45" Kabupaten Kuningan tahun 2016 prevalensi asfiksia 254 kasus $(19,7 \%)$, kehamilan postterm 51 kasus (3,9\%).Penelitian ini bertujuan untuk mengetahuihubungan antara kehamilan postterm dan ketuban pecah dini dengan asfiksia pada bayi baru lahir di RSUD "45" Kabupaten Kuningan.

Jenis penelitian yang digunakan adalahcase control dengan mengambil sampel sebanyak 254 bayi yang mengalami asfiksia sebagai kasus dan 254 bayi yang tidak asfiksia sebagai kontol.Pengambilan sampel dilakukan dengan teknik puposive sampling, data dianalisis dengan analisis Chi Square. Hasil analisis menunjukan ada hubungan antara kehamilan postterm dengan asfiksia pada bayi baru lahir ( $\mathrm{p}=$ 0,037 ) dan ada hubungan antara ketuban pecah dini dengan asfiksia pada bayi baru lahir $(\mathrm{p}=0,000)$ pada taraf kesalahan 0,05.

Petugas kesehatan dan pemerintah hendaknya bekerja sama dalam rangka meningkatkan kualitas pelayanan kesehatan untuk mencegah kehamilan postterm dan ketuban pecah dini serta untuk peneliti lain diharapkan dapat melaksanakan penelitian dengan data primer.
\end{abstract}

Kata kunci : Kehamilan Postterm, Ketuban Pecah Dini, Asfiksia

\section{PENDAHULUAN}

Tujuan pembangunan kesehatan antara lain tercapainya kemampuan untuk hidup sehat bagi setiap penduduk agar dapat mewujudkan derajat kesehatan masyarakat yang optimal, sebagai salah satu unsur kesejahteraan umum dari tujuan nasional. Untuk dapat meningkatkan derajat kesehatan masyarakat banyak hal yang perlu di perhatikan, salah satu diantaranya yang dipandang mempunyai peranan yang cukup penting ialah menyelenggarakan pelayanan kesehatan yang menyeluruh dan terpadu dalam rangka menurunkan angka morbilitas dan mortalitas (Prawirohardjo, 2013).

Morbiditas dan mortalitas pada wanita hamil dan bersalin Begitupula berbagai gangguan atau masalah pada bayi baru lahir dapat terjadi dan mengakibatkan kesakitan dan kematian pada bayi baru lahir.Hal ini dapat di lihat dari tingginya angka kesakitan dan kematian bayi baru lahir.Diperkirakan 2/3 kematiaan bayi dibawah umur satu tahun, terjadi pada masa 0-7 hari pertama setelah lahir. Menurut WHO, hal teersebut dapat dihindari apabila penanganan awal dilaksanakan dengan cepat dan tepat.Penyebab utama kematian bayi baru lahir adalah akfiksia yang merupakan urutan pertama di pulau jawa dan bali kemudian diikuti infeksi. Kematian bayi baru lahir adalah kemaatian bayi yang terjadi sebelum, selama dan sesudah persalinan dalam kurun waktu setelah umur 
kehamilan 28 minggu hingga 7 hari setelah persalinan.

Terjadinya asfiksia pada bayi baru lahir akibat depresi pernafasan pada janin dikarenakan factor antepartum dan factor intrapartum. Faaktor antepartum diantaranya umur ibu lebih dari 35 tahun, kehamilan preterm, kehamilan ganda, kehamilan posterm, oligohidramnion dan cacat bawaan dimana factor usia dari kehamilan saat persalinan yang tidak pada waktunya seperti kehamilan preterm dan posterm merupakan factor yang sangat beresiko terjadinya asfiksia pada bayi baru lahir dan didapatkan pula kejadian kehamilan posterm di RSUD 45 Kabupaten Kuningan yang cukup tinggi yaitusekitar $3,9 \%$ dari 1290 persalinan bila dibandingkan dari hasil penelitian yang dilaporkan oleh beberapa ahli di Indonesia yang menyebutkan bahwa angka kejadia posterm berkisar antara 3,5 $-14 \%$. Sedangkan dari factor intrapartum diantaranya persalinan SC, pemakaian anastesi umum, ketuban pecah dini, partus lama, dan denyut jantung janin abnormal. Dimana hasil studi pendahuluan didapatkan tingginya angka kejadian KPD yaitu sekitar $19,6 \%$ dari 1365 persalinan yang merupakan kejadian paling tinggi dari komplikasi saat persalinan di RSUD 45 Kuningan (Register ruang kebidanan RSUD 45 Kabupaten Kuningan).

Ketuban pecah dini merupakan keadaan dimana cairan ketuban keluar sebelum terjadinya persalinan.Keadaan KPD merupakan masalah penting dalam obstetric berkaitan dengan kelahiran premature dengan terjadinya infeksi yang meningkatkan mordibitas dan mortalitas perninatal.Kira-kira $12 \%$ dari semua kehamilan mengalami KPD. KPD adalah salah satu factor penyebab asfiksia pada bayi baru lahir (Manuaba,2010).

Berdasarkan hasil studi pendahuluan ditemukankan tingginya angka kejadian asfiksaia pada bayi baru lahir yaitu sebanyak 257 kasus ( 19,7\%) dari 1290 bayi lahir di RSUD 45 Kabupaten Kuningan. Didapatkan bahwa pada ibu dengan umur kehamilan lebih dari 42 minggu yang melahirkan bayi dengan asfiksia sekitar $41,17 \%$ sedangkan yang tidak mengalami asfiksia sekitar 58,83\% hal ini, tidak sejalan dengan teori yang meyebutkan kehamilan posterm merupakan salah satu penyebab terjadinya asfiksia pada bayi baru lahir mengingat bahwa berkurangnya nutrisi dan O2 untuk janin akibat insufisiensi plasenta, semakin tuanya kehamilan menyebabkan janin mengalami asfiksi intrauterine ( Manuaba, 2010).

Sedangkan angka kejadian asfiksia pada bayi baru lahir akibat KPD $45,85 \%$ dan selebihnya tidak mengalami asfiksia. Berdasarka uraian maka penulis tertarik untuk melakukan penelitain apakah ada hubungan antara kehamilan posterm dan KPD dengan asfiksia di RSUD 45 Kuningan tahun 2016.

\section{METODE PENELITIAN}

\section{A. Desain Penelitian}

Desain penelitian merupakan suatu kerangka acuan bagi pengkajian hubungan antar variabel penelitian. Dalam pengertian tertentu desain menyatakan observasi atau pengukuran apa saja yang harus dilakukan, bagaimana cara melakukan pengukuran dan bagaimana pula melakukan analisis terhadap hasil -hasil pengukuran (Sunyoto, 2012).

Penelitian yang dilakukan adalah studi korelasi yang merupakan penelitian atau penelaahan hubungan antara dua variabel pada suatu situasi atau sekelompok. subjek dengan pendekatan case control. Penelitian case control adalah penelitian yang melihat kasus -kasus penyakit atau status kesehatan pada masa sekarang, akan tetapi faktor resikonya diidentifikasi terjadinya atau dilihat ke masa lalu.

\section{B. Populasi dan Sampel}

\section{Populasi}

Populasi adalah keseluruhan objek penelitian atau objek yang diteliti (Sunyoto, 2012). Populasi disini adalah semua bayi yang lahir hidup di BRSUD "45" 
Kabupaten Kuningan pada tahun 2016 sebanyak 1290 orang.

\section{Sampel}

Sampel adalah sebagian atau seluruh obyek yang diteliti dan dianggap mewakili populasi (Sunyoto, 2012), dalam penelitian ini menggunakan teknik pengambilan sampel Purposif sampling yaitu suatu penetapan sampel dengan memilih sampel diantara populasi sesuai yang dikehendaki peneliti, sehingga sampel tersebut dapat mewakili karakteristik populasi yang telah dikenal selanjutnya.

Adapun kriteria inklusi meliputi :

a) Hari pertama haid terakhir diketahui.

b) Kehamilan tunggal.

c) Letak dan presentasi normal.

d) Ada data tentang riwayat kehamilan, persalinan dan bayi baru lahir lengkap.

\section{Kriteria ekslusi meliputi :}

1. Ibu dengan catatan rekam medik yang tidak mencantumkan nomor register.

2. Ibu yang tidak memenuhi kriteria inklusi.

3. Adapun yang menjadi kelompok kasus dalam penelitian ini adalah ibu yangmelahirkan bayi asfiksia di RSUD "45" Kabupaten Kuningan sebanyak 254 orang sedangkan yang menjadi kelompok kontrol adalah ibu yang melahirkan bayi tidak asfiksia di RSUD "45" Kabupaten Kuningan sebanyak 254 orang.

\section{Tempat dan Waktu Penelitian}

Penelitian akan dilaksanakan di RSUD "45" Kabupaten Kuningan pada tanggal 12 sampai dengan 14 Juni tahun 2016.

\section{Alat dan Proses Pengumpulan Data.}

Data yang dikumpulkan dalam penelitian ini adalah data sekunder diambil dari data bayi bayi baru lahir yang mengalami asfiksia dan tidak mengalami asfiksia di RSUD "45" Kuningan pada tahun 2005 dari catatan rekam medik ruang perinatologi yang sebelumnya peneliti meminta surat pengantar dari institusi (STIKES Ngudi Waluyo) kemudian menyerahkan ke tempat penelitian yaitu RSUD "45" Kuningan untuk mendapatkan izin melakukan penelitian di tempat tersebut.

Setelah mendapatkan izin peneliti mengambil data bayi baru lahir di ruang perinatologi kemudian mengambil data ibu bersalin di ruang bersalin. Dalam penelitian ini digunakan lembaran formulir pengumpulan data kemudian data yang diperoleh dimasukkan sesuai dengan variabel -variabel yang ada dalam master data (Sunyoto, 2012).

\section{E. Etika Penelitian.}

1. A nonimity (tanpa nama)

2. Untuk menjaga kerahasiaan responden, maka dalam lembar pengumpulan data peneliti tidak mencantumkan nama.

3. Conjidentialigz (kerahasiaan)

4. Dalam penelitian ini diperhatikan asas kerahasiaan yaitu menjaga informasi dari catatan medis sampel atau responden dan tidak menyebarluaskan.

\section{F. Pengolahan Data}

Setelah data diperoleh, kemudian dilakukan pengolahan dengan tahapan sebagai berikut :

\section{Memeriksa data (Editing)}

Tahapan ini dimaksudkan untuk melakukan pemeriksaan terhadap data yangdikumpulkan dengan memeriksa kelengkapan dan kesalahan pengisian data.

\section{Memberi kode (Coding)}

Setelah data terkumpul dan diedit selanjutnya data diberi kode untuk mempermudah pengolahan data. Kode yang digunakan adalah:

\section{a. Kehamilan posuerm}


Kode 1 : Kehamilan postterm

Kode 2 : Kehamilan tidak postterm

\section{b. Ketuban pecah dini}

Kode 1 : Ketuban pecah dini

Kode 2 : Ketuban tidak pecah dini

\section{c. Asfiksia}

Kode 1 : Asfiksia

Kode 2 : Tidak asfiksia

\section{Menyusun data (Tabulating)}

Penyusunan data merupakan pengorganisasian data sedemikian rupa agar data mudah dijumlahkan, disusun dan ditata untuk disajikan dan dianalisis.

\section{Analisis Data}

Analisis data yang dilakukan pada penelitian ini adalah:

1. Analisis univariat yaitu menganalisis tiap -tiap variabel penelitian ini secara deskriptif dan menghitung distribusi frekuensi dan proporsinya untuk menggambarkan kejadian kehamilan postterm, ketuban pecah dini dan asfiksia.

2. Analisis bivariate yaitu analisis yang dilakukan untuk melihat hubungan kedua variable yang meliputi variable terikat yaitu afiksia dan variable bebas yaitu kehamilan postterrn dan ketuban pecah dini dengan mlakuakan uji hipotesis. Jenis uji hipotesis yang digunakan adalah Chi Square yaitu untuk mencari hubungan dan membuktikan hipotesis hubungan dua variabel. Dengan menggunakan rumus

$$
X^{2}=\frac{E(0-E)^{2}}{E}
$$

\section{Keterangan:}

$\mathrm{X}$ : Chi Square

$\mathrm{O}$ : hasil pengamatan

$\mathrm{E}$ :Nilai hasil ekpektasi

Selanjutnya dihitung derajat kebebasan (dk) dengan rumus :
$D k=($ Jumlah baris -

1). (jumlah kolom -1)

Untuk dapat membuat keputusan tentang hasil uji hipotesis diterima atau ditolak, maka nilai Chi Square hitung selanjutnya dibandingkan dengan Chi Square tabel dengan $\mathrm{dk}$ dan taraf kesalahan 0,05. bila ditemukan Chi Square hitung lebih besar dari Chi Square tabel maka hipotesis diterima dan apabila Chi Square hitung lebih kecil dari Chi Square tabel maka hipotesis ditolak (Arikunto, 2002).

Pada penelitian case control kita mulai dengan mengambil kelompok kasus (A $+\mathrm{C})$ dan kelompok kontrol $(\mathrm{B}+\mathrm{D})$. Oleh karena kontrol justru dipilih mereka yang tidak sakit maka tidak dapat dihitung kejadian penyakit, dan tidak diketahui preporsi kasus dan kontrol terhadap keadaan yang sebenarnya pada populasi. Sehingga kita tidak dapat menghitung insiden pada kasus maupun kontrol. Yangdapat dinilai adalah berapa seringnya terdapat pajanan pada kasus dibandingkan pada kontrol, yaitu rasio adds (RO) (Sunyoto, 2012).

$\mathrm{RO}=$ adds pada kasus $:$ adds pada kontrol

$=$ (proporsi kasus dengan faktor risiko) : (proporsi kontrol dengan faktor risiko)

(proporsi kasus tanpa faktor risiko) (proporsi dengan tanpa faktor risiko)

$$
\begin{aligned}
& =\frac{\mathrm{A} /(\mathrm{A}+\mathrm{C}): \mathrm{B} /(\mathrm{B}+\mathrm{D})}{\mathrm{A} / \mathrm{C}: \mathrm{B} / \mathrm{D}: \overline{\mathrm{AD} / \mathrm{BC}}} \\
& =\mathrm{C} /(\mathrm{A}+\mathrm{C}) \mathrm{D} /(\mathrm{B}+\mathrm{D})
\end{aligned}
$$

\section{HASIL PENELITIAN}

\section{A. Gambaran setiap variabel.}

\section{Kejadian postterm.}

Distribusi responden berdasarkan umur kehamilan saat persalinan di RSUD 45 Kabupaten Kuningan pada tahun 2017. 
Berdasarkan tabel 1 dapat diketahui bahwa distribusi frekuensi terjadinya persalinan dengan kehamilan yang tidak postterm sebanyak 51 kasus (3,95\%), sedangkan persalinan dengan kehamilan postterm sebanyak 1239 kasus $(96,05 \%)$.

\section{Kejadian ketuban pecah dini.}

Kejadian Ketuban Pecah Dini dapat dianalisa pada tabel berikut ini:

\section{Tabel 1}

Distribusi responden berdasarkan komplikasi persalinan dengan KPD di RSUD 45 Kabupaten Kuningan

\begin{tabular}{ccc}
\hline Kejadian & $\mathrm{N}$ & $\%$ \\
\hline KPD & 253 & 19,6 \\
Tidak KPD & 1037 & 80,4 \\
\hline Jumlah & 1290 & 100 \\
\hline
\end{tabular}

Berdasarkan Tabel 1 dapat dilihat bahwa distribusi frekuensi terjadinya persalinan dengan tidak KPD sebanyak 1037 kasus $(80,4 \%)$, sedangkan persalinan tanpa KPD sebanyak 253 kasus $(19,6 \%)$.

\section{B. Hasil penelitian}

\section{Hubungan antara kehamilan postterm dengan asfiksia pada bayi baru lahir}

Hubungan antara kehamilan possterm dengan asfiksia pada bayi baru lahir .Hasil perhitungan uji statistic Chi Square diperoleh harga $X^{2}=5,101$ dan $p=0,024$ dengan dengan $\mathrm{X}^{2}$ tabel $=3,841$, derajat kebebasan (dk) 1, maka hipotesis diterima, artinya ada hubungan yang signifikan antara kehamilan postterm dengan asfiksia pada bayi baru lahir pada $\alpha=0,05$. Dan besarnya risiko untuk asfiksia bayi baru lahir pada ibu bersalin dengan kehamilan postterm sebesar 2,5 kali lebih besar dibandingkan dengan ibu bersalin yang tidak postterm $(\mathrm{OR}=2,5)$ '

\section{Hubungan antara ketuban pecah dini dengan asfiksia pada bayi baru lahir}

Hubungan antara ketuban pecah dini dengan asfiksia pada bayi baru lahir. Hasil perhitungan uji statistic Chi Square diperoleh harga $X^{2}=35,071$ dan $p=0,000$ dengan dengan $\mathrm{X}^{2}$ tabel $=3,841$, derajat kebebasan (dk) 1, maka hipotesis diterima, artinya ada hubungan yang signifikan antara ibu bersalin dengan ketuban pecah dini dengan asfiksia pada bayi baru lahir pada $\alpha=0,05$. Dan besarnya risiko untuk asfiksia bayi baru lahir pada ibu bersalin dengan kehamilan postterm sebesar 3,2 kali lebih besar dibandingkan dengan ibu bersalin yang tidak postterm $(\mathrm{OR}=3,2)$

\section{PEMBAHASAN}

\section{A. Analisis Univariat}

\section{Umur kehamilan (potterm) .}

Hasil penelitian menunjukan bahwa distribusi kejadian kehamilan pastian: di BRSUD “45" Kabupaten Kuningan pada tahun 2005 sebanyak 51 kasus (3,95\%) dari 1290 persalinan. Angka tersebut termasuk pada angka rata -rata untuk kejadian kehamilan postterm yang dilaporkan oleh beberapa peneliti. Manuaba (2002) yang melaporkan bahwa kejadian postterm berkisar antara $10 \%$ dari seluruh kehamilan. Namun sebagian diantaranya mungkin tidak benar benar postierm disebabkan kekeliruan dalam memperkirakan usia kehamilan, karena banyak wanita yang sering lupa akan tanggal haid terakhirnya. Ketika USG digunakan dalam menentukan usia kehamilan yang akurat kejadian kehamilan postterm menurun.

Tingginya angka kejadian kehamilan postierm di BRSUD "45" Kabupaten Kuningan dikarenakan kurangnya kesadaran dari ibu hamil akan bahaya dari kehamilan yang melebihi waktu taksiran persalinan, sebagian besar dari mereka hanya menunggu untuk terjadinya kontraksi padahal mereka telah mengetahui kapan waktu yang tepat untuk ibu bersalin. Selain itu ibu hamil kadang tidak mengetahui secara pasti kapan terakhir ia mendapat haid untuk mempermudah tenaga 
kesehatan menentukan usia kehamilan dan waktu yang tepat persalinan, sehingga pada saat dilakukan Pemeriksaan yang lebih akurat di rumah sakit dengan USG baru diketahui bahwa ibu tersebut mengalami kehamilan postterm.

Prawirohardjo (2013) menyatakan bahwa waktu terbaik untuk persalinan adalah pada umur kehamilan $39 \quad-41$ minggu, jika persalinan dilakukan pada usi kehamilan lebih dari 42 minggu maka kemungkinan untuk terjadinya mortalitas dan morbiditas janin karena itu diperlukan adanya suatu sistem pengolahan yang benar benar cermat agar tidak terjadi umur kehamilan yang melebihi 42 minggu. Apabila persalinan dengan kehamilan postterm sudah terjadi maka penatalaksanaan dalam proses persalinan diperlukan pemantauan keadaan ibu bersalin dan janin.

Tenaga kesehatan dapat memahami sacara mudah variasi dari hubungan antarorgan diantara janin dan ibu yang dapat menyebabkan persalinan tidak terjadi pada waktunya. lbu hamil yang pernah mengalami satu kali kehamilan postterm akan menghadapi peningkatan risiko untuk terjadinya kembali keadaan yang sama pada kehamilan berikutnya, oleh karena itu tenaga kesehatan perlu selalu melakukan pengkajian pada saat pemeriksaan kehamilan pertama akan riwayat persalinan dan kehamilan terdahulu agar dapat melakukan pemantauan kehamilan lamanya persalinan secara tepat.

\section{Ketuban Pecah Dini (KPD)}

Hasil penelitian menunjukan bahwa distribusi frekuensi kejadian kemban Pecah Dini di BRSUD "45" Kabupaten Kuningan pada tahun 2005sebesar 19,6\% dari seluruh persalinan. Angka ini merupakan angka yang cukup tinggi apabila dibandingkan dengan hasil penelitian sebelumnya. Taber menyebutkan bahwa angka kejadian Ketuban pecah Dini berkisar antara 7 12\% dari seluruh kehamilan. Kejadian Ketuban pecah Dini kira -kira $12 \%$ dari semua kehamilan.
Tingginya angka kejadian Ketuban Pecah Dini di BRSUD "45" Kabupaten Kuningan ini sebagian besar disebabkan karena kurangnya pengetahuan ibu untuk membedakan antara tanda -tanda dimulainya persalinan dengan tanda tanda adanya ketuban pecah dini, ibu hamil menganggap bahwa keluarnya cairan dari vagina merupakan salah satu dari tanda dimulainya persalinan dan mereka menganggap bahwa bila belum adanya kontraksi uterus atau dimulainya his maka persalinan masih berlangsung lama walaupun sudah terjadi pengeluaran cairan pervaginam.

Periode menunggu ini yang menjadi masalah dalam penanganan dari Ketuban Pecah Dini itu sendiri dimana ibu tidak segera datang ke petugas kesehatan untuk mendapatkan penanganan segera dari komplikasi Ketuban Pecah Dini. Penyebab dari Ketuban Pecah Dini dapat terjadi karena : serviks yang inkomplit, overdistensi uterus seperti kehamilan ganda dan polyhidramm'on, kelainan letak, adanya pengaruh dari luar yang mengakibatkan melemahnya selaput ketuban seperti infeksi genitalia serta kelainan genetik dari faktor keturunan. Penyebab inilah yang kadang sulit untuk diketahui terutama pada servik yang inkomplit dan kelainan genetik sehingga sulit pula untuk dilakukan pencegahannya.

Ketuban Pecah Dini dapat menyebabkan adanya infeksi intrauterin, kelainan presenatasi janin, prolapsus funiculi, partus prematur dan asfiksia pada bayi baru lahir yang terkait dengan adanya oligohidramnion yaitu cairan amnion yang semakin berkurang karena adanya pengeluaran sebelum terjadinya persalinan.Maryunani (2013) meyatakan karena risiko infeksi intrauterin meningkat pada Ketuban pecah Dini, penting bagi tenaga kesehatan untuk membuat diagnosis yang akurat tanpa meningkatkan risiko infeksi. Kejadian infeksi meningkat dan berhubungan langsung dengan seringnya dilakukan pemeriksaan pelvik, oleh karena itu semakin sedikit dilakukan pemeriksaan 
pelvik semakin kecil risiko terjadinya infeksi.

Mengingat bahwa $80-85 \%$ wanita pada semua kehamilan dengan Ketuban Pecah Dini akan bersalindalam 24 jam dan sisanya akan bersaln dalan 72 jam maka bidan tidak segera melakukan pembedahan sesar dan hanya melakukan induksi persalinan untuk menunggu terjadinya persalinan spontan dalam jangka waktu 24 jam dengan tetap melakukan pemantauan pada keadaan ibu dan janin.

\section{B. Analisis Bivariat}

\section{Hubungan antara kehamilan postterm dengan asiiksia pada bayi baru lahir.}

Hasil analisis Chi Square menunjukkan bahwa terdapat hubungan antara kehamilan postterm dengan asiiksia pada bayi baru lahir $(p=0,024)$. Hal ini sesuai dengan teori yang menyatakan kehamilan postterm dapatmeningkatkan kejadian asiiksia bayi baru lahir Dan besarnya risiko untuk terjadinya asfiksia pada bayi baru lahir pada kehamilan postterm cukup besar yaitu 2,5 kali lebih besar dibandingkan dengan kehamilan tidak postterm.

Hasil penelitian ini sesuai dengan hasil yang ditemukan pada seluruh penelitian yang pernah dilakukan tentang hubungan antara kehamilan postierm dengan risiko morbiditas perinatal, dimana terdapat hubungan yang sangat bermakna dan meningkatnya kehamilan postierm secara signifikan meningkatkan morbiditas bayi dan besarnya risiko untuk terjadinya asiiksia bayi pada menit pertama setelah lahir pada kehamilan postterm dan aterm menunjukkan perbedaan yang bermakna, dimana risiko terjadinya asfiksia cukupbesar pada kehamilan postterm yaitu 3 kali lebih besar dibandingkan dengan kehamilan aterm.

Kehamilan postterm terjadi penurunan jumlah cairan amnion (oligohidramnion). Dengan adanya oligohidramnion akan meningkatkan kemungkinan terjadinya kompresi tali pusat, sehingga sirkulasi dan oksigenasi ke janin terganggu dan akhirnya dapat terjadi kegawatan pada janin akibat hipoksia janin intrauterin. Volume cairan amnion mencapai puncaknya pada umur kehamilan 34 -36 minggu mencapai jumlah kurang lebih $1000 \mathrm{ml}$ kemudian secara bertahap berkurangdengan semakin tuanya kehamilan.

Pada umur kehamilan 40 minggu volume cairan ketuban berkurang menjadi kurang lebih $800 \mathrm{ml}$ dan pada kehamilan 42 minggu atau lebuh volume caran ketuban menunjukkan penurunan yang cukup besar menjadi $250300 \mathrm{ml}$. Berkurangnya cairan ketuban ini akan meningkatkan adanya kompresi tali pusat sehingga sirkulasi dan oksigenasike janin terganggu dan akhirnya akan terjadi asfiksia pada saat bayi lahir akibat hipoksia janin intrauterin. Dan adanya cairan amnion yang diwarnai oleh mekonium merupakan faktor risiko meningkatnya morbiditas bayi baru lahir mengingat kemungkinan aspirasi mekonium dapat terjadi terutama selama proses persalinan.

Adanya aspirasi mekonium akan menyebabkan obstruksi pada saluran nafas yang berakibat gawat nafas pada bayi baru lahir disamping juga akibat reaksi kimiawi yang ditimbulkan akan menyebabkan hipoksi janin sampai kematian. Dan hal ini dapat mengakibatkan asfiksia intrauterin dan aspirasi mekonium yang berlanjut ke astiksia pada daat bayi baru lahir. Prawirohardjo (1999) menyebutkan bahwa adanya mekonium dapat dikarenakan proses fisiologis sebagai tanda dari semakin maturnya fungsi atau akibat aktivitas refleks vagal dari traktus gastrointestinal, namin lebi sering akibat hipoksia janin dalam rahim terutama pada kehamilan postterm dimana terjadi insufisiensi uteroplasenta.

Roberta dkk (1993) menyatakan bahwa terdapat $10 \%$ bayi baru lahir pada kehamilan postterm mengalami aspirasi mekonium dan $37,5 \%$ dari bayi baru lahir tersebut meninggal. Risiko morbiditas dan mortalitas bayi baru lahir pada kehamilan postterm meningkat 2 sampai 3 kali dari 
kehamilan aterm. Menurut Manuaba (2002) bahwa berkurangnya nutrisi dan 02 ke janin akibat isuflsiensi plasenta dengan semakin tuanya kehamilan menyebabkan gawat janin terutama saat persalinan yang menyebabkan asfiksia intrauterin yang berlanjut ke asfiksia bayi baru lahir.

Akibat adanya gangguan suplai 02 dan nutrisi untuk hidup dan tumbuh kembang janin intrauterin, sirkulasi uteroplasenta berkurang sampai $50 \%$. Volume air ketuban jadi kurang karena mulai terjadi absorbsi. Dari penelitian Miller (1981) mendapatkan $14,6 \%$ bayi yang lahir dari kehamilan postterm dengan nilai APGAR 0 -3 dan 13,4\% dengan nilai APGAR 4 -6 pada menit pertama, dibandingkan dengan $5,4 \%$ dan $10 \%$ pada kehamilan cukup bulan.

Sedangkan penilaian 5 menit pada kehamilan lebih bulan didapatkan $8,5 \%$ dengan nilai APGAR kurang dari 7 , dibandingkan dengan 3,175pada kehamilan cukup bulan. Disamping itu didapatkan angka kematian bayi baru lahir pada kehamilan postterm akibat asfiksia adalah 2 kali lebih banyak dibandingkan dengan kehamilan cukup bulan. Dalam penelitian ini menunjukan bahwa ibu bersalin dengan kehamilan postterm mempunyai risiko untuk terjadinya asfiksia pada bayi baru lahir sebesar 2,5 kali lebih besar dibandingkan dengan ibu bersalin dengan umur kehamilan tidak postterm karena terjadi astiksia intrauterin pada saat proses persalinan. Oleh karena itu diharapkan seorang ibu hamil dan tenaga kesehatan dapat melakukan deteksi dini pada saat pemeriksaankehamilan agar tahu kapan seharusnya waktu yang tepat kapan ibu hamil tersebut melahirkan sehingga tidak terjadi komplikasi saat persalinan yaitu asfiksia pada bayi baru lahir.

\section{Hubungan antara Ketuban Pecah Dini dengan Asfiksia pada Bayi Baru Lahir.}

Hasil analisis Chi Square menunjukan bahwa terhadap hubungan antara ketuban pecah dini dengan asfiksia pada bayi baru lahir $(\mathrm{p}=0,001)$. Hal ini sesuai dengan Manuaba (2002) yang menyatakan bahwa ketuban pecah dini dapat meningkatkan kejadian asfiksia bayi baru lahir. Dan besarnya resiko untuk terjadinya afiksia pada bayi lahir pada ketuban pecah dini cukup besar yaitu 3,2 kali lebih besar dibandingkan dengan persalinan dengan tanpa ketuban pecah dini.

Terjadinya afiksia pada bayi baru lahir berkaitan dengan adanya persalinan dengan ketuban pecah dini yang menyebabkan terjadinya oligohidramnion karena pengeluaran cairan amnion secara terus menerus pada saat belum terjadinya persalinan dimana dengan adanya oligohidramnion akan meningkatkan terjadinya kompresi tali pusat sehingga sirkulasi dan oksigenasi ke janin terganggu dan akhirnya dapat terjadi kegawatan pada janin akibat hipoksia janin intrauterine yang berlanjut ke afikksia pada bayi baru lahir.

Oligohidramnion yang berhubungan dengan ketuban pecah dini yang kurang dari 24 minggu kehamilan dapat menyebabkan terjadinya hipoplasi paru. Faktor-faktor yang mungkin bertanggung jawab antara lain adalah janin berhimpitan dengan kompresi toraks, terbatasnya janin dan terganggunya produksi dan cairan paruparu. Dalam kehidupan intrauterine paruparu tidak berperan dalam pertukaran gas.

Dalam persalinan terdapat beberapa perubahan terjadi pada paru -paru agar dapat berfungsi sebagai alat pertukaran gas dimana terjadi pengembangan paru paru untuk pertama kalinya karena tekanan jalan lahir saat proses persalinan. Hal ini tidak dapat terjadi pada persalinan preterm dimana belum terbentuknya organ paru secara sempurna. Dalam kehamilan alveoli janinberisi cairan yang dibentuk dalam paru -paru, pada saat persalinan diperlukan tekanan yang besar untuk mengeluarkan cairan tersebut agar paru -paru dapat berkembang untuk pertama kali. Pengeluaran cairan paru dipecepat oleh pernafasan segera setelah lahir, pada sebagian besar bayi pernafasan pertama sangant efektif untuk mengembangkan 
alveoli dan menggantikan cairan paru paru dengan udara.

Masalah pengeluaran cairan paru paru terjadi pada bayi yang mengalami gangguan pada pengembangan paru dalam upaya pernafasan pertama. Keadaan ini dapat dilihat pada bayi yang lahir dengan asfiksia dengan menunjukkan usaha nafas yang lemah. Bayi yang tidak dapat segera bernafas secara spontan dan teratur dapat diasumsikan bahwa pengambangan alveoli tidak terjadi dan paru _ paru tetap terisi cairan. Melakukan pernafasan buatan pada bayi seperti ini diperlukan tekanan tambahan untuk membuka alveoli dan pengeluaran cairan.

Peredaran darah paru paru pada bayi dengan asliksia akan menunjukkan kontriksi pembuluh darah dalam paru -paru. Pembuluh darah pada bayi normal biasanya terbuka akan tetapi pada bayi asfiksia akan tetap tertutup sehingga nenunjukan keadaan hipoksia dan asidosis dengan demikian sirkulasi darah janin akan berkurang. Karena risiko infeksi intrauterin meningkat pada Ketuban pecah Dini, penting bagi tenaga kesehatan untuk membuat diagnosis yang akurat tanpa meningkatkan risiko infeksi.

Kejadian infeksi meningkat dan berhubungan langsung dengan seringnya dilakukan pemeriksaan pelvik, oleh karena itu semakin sedikit dilakukan pemeriksaan pelvik semakin kecil risiko terjadinya infeksi. Mengingat bahwa $80-85 \%$ wanita pada semua kehamilan dengan Ketuban Pecah Dini akan bersalin dalam 24 jam dan sisanya akan bersaln dalan 72 jam maka bidan tidak segera melakukan pembedahan sesar dan hanya melakukan induksi persalinan untuk menunggu terjadinya persalinan spontan dalam jangka waktu 24 jam dengan tetap melakukan pemantauan pada keadaan ibu dan janin.

Dalam penelitian ini menunjukkan bahwa ibu bersalin dengan Ketuban Pecah Dini mempunyai risiko untuk terjadinya astiksia pada bayi baru lahir sebesar 3,2 kali lebih besar dibandingkan dengan ibu bersalin dengan tanpa komplikasi Ketuban
Pecah Dini. Oleh karena itu diharapkan seorang ibu hamil yang mengalami komplikasi Ketuban Pecah Dini diharapkan dilakukan penanganan segera agar tidak terjadi komplikasi saat persalinan yang menyebabkan asfiksia pada bayi baru lahir.

\section{Keterbatasan Penelitian}

Penelitian yang telah dilakukan di RSUD "45" Kabupaten Kuningan ini menggunakan metode penelitian case control yang mempunyai keterbatasan yaitu pada pemilihan sampel untuk kelompok kontrol karena banyak faktor risiko lain yang harus dikendalikan seperti faktor risiko lain yang dapat mengakibatkan asiiksia bayi baru lahir seperti dari faktor ibu, faktor plasenta, faktor janin, faktor bayi, faktor ante dan intrapartum yang lain.

Dan penelitian ini hanya mengambil data sekunder pada populasi ibu bersalin yang melahirkan bayi baru lahir dengan asfiksia selama tahun 2005, maka adanya kekurangan pengisian catatan rekam medic seperti tidak tercantumnya diagnosis dari kehamilan postterm. KPD dan afiksia akan berpengaruh terhadap validasi hasil penelitian.

\section{KESIMPULAN}

1. Angka kejadian kehamilan postterm di RSUD "45" Kabupaten Kuningan sekitar 3,9\% dari 1290 persalinan. Angka kejadian ketuban pecah dini di RSUD " 45 " Kabupaten Kuningan sekitar $19,6 \%$ dari 1290 persalinan.

2. Ada hubungan antara kehamilan postterm dengan kejadian asfiksia pada bayi baru lahir $(\mathrm{p}=0,024)$ dan besarnya risiko untuk terjadinya asfiksia bayi baru lahir pada kehamilan postterm adalah 2,5 kali lebih besar dibandingkan dengan kehamilan yang tidak postterm (OR-2,5).

3. Ada hubungan hubungan antara ketuban pecah dini dengan kejadian asfiksia pada bayi baru lahir $(\mathrm{p}=0,001)$ dan besarnya risiko untuk terjadinya 
asfiksia bayi baru lahir pada ibu bersalin dengan ketuban pecah dini adalah 3,2 kali lebih besar dibandingkan dengan ibu bersalin yang tidak ketuban pecah dini $(\mathrm{OR}=3,2)$.

\section{DAFTAR PUSTAKA}

Cristina, Y.(2012). Esensial obstetri dan ginekologi edisi 3.KDT: Jakarta

Machfoedz, I dkk.(2005). Metodologi penelitian bidang kesehatan, keperawatan, dan kebidanan.Fitramaya : Yogyakarta

Manuaba, dkk.(2010). Ilmu kebidanan, penyakit kandungan, dan KB. EGC: Jakarta
Maryunani, dkk.(2013). Asuhan kegawatdaruratn maternal dan neonatal. TIM. Jakarta

Pontoh, Idham. (2013). Dasar dasar ilmu kesehatan masyarakat. In Media: Jakarta

Setiyaningrum, dkk.(2014). Pelayanan keluarga berencana dan kesehatan reproduksi.Tras Info Media. Jakarta

Sunyoto, Danang. (2012). Biostatistik untuk kebidanan. Muha Medika: Yogyakarta

Prawirohardjo. (2010). Ilmu kandungan. edisi kedua, cetakan ketiga. Yayasan Bina Pustaka Sarwono Prawirohardjo: Jakarta

Prawirohardjo.(2013). Ilmu Kebidanan.edisi keempat, cetakan ketiga. Yayasan Bina Pustaka Sarwono Prawirohardjo: Jakarta 